\title{
PROFILE OF SUICIDAL HANGING PRESENTED TO A TERTIARY CARE HOSPITAL: A DESCRIPTIVE STUDY
}

\author{
Kitulwatte I.G.D., Edirisinghe P.A.S.', Senarathne U.D. ${ }^{2}$, Mendis H.K.N.L.P., \\ Wijesinghe P.R. ${ }^{1} \&$ Fernando A. \\ 'Department of Forensic Medicine, Faculty of Medicine, University of Kelaniya, Sri Lanka \\ ${ }^{2}$ Department of Bio-chemistry, Faculty of Medicine, University of Sri Jayawardenepura, \\ Sri Lanka
}

Corresponding Author: Kitulwatte I.G.D.

Email: indiradgk@yahoo.com

(D) https:/ / orcid.org/ 0000-0002-6108-9059

\begin{abstract}
When a body is found suspended, the forensic pathologist is expected to give an opinion on the manner of death excluding or confirming possible criminal involvement. Conclusion is easy when findings are classic. However, it is a dilemma when there are atypical findings.
\end{abstract}

\section{Objectives}

To analyze the autopsy findings in deaths due to hanging and to have an insight into the typical and atypical findings in order to appreciate the difficulties in interpretation.

\section{Methods}

A retrospective descriptive study on post mortem records of the victims of hanging during a period of three years, brought to a tertiary care hospital. The findings of death investigation including background information, scene, and autopsy examination were analysed.

\section{Results}

Total of hundred and twelve records of deaths due to suicidal hanging were perused and $97(86.6 \%)$ out of them were males. The majority of victims $(37 \%)$ were in the age group of 21 to 40 years. The complete suspensions was identified in most cases (79.5\%). The commonest ligature material (25\%) was the coir rope. Sixty-nine were having a ligature mark rising to an inverted ' $\mathrm{V}$ '. Classic signs were observed in $47 \%$ and the presence of classic signs was significantly associated with partial suspension $(p<0.001)$. Internal injuries were observed in $34 \%$ and the majority were fractures. Internal injuries had no significant association to the degree of suspension $(p=0.11)$.

All articles in Sri Lanka Journal of Forensic Medicine, Science \& Law are licensed under the terms of the Creative Commons Attribution-Non Commercial 4.0 International License. 


\section{Conclusion}

The findings in hanging vary, and may be found in many combinations sometimes with exceptions to the generally accepted. Awareness of these combinations and the exceptions are of crucial importance in coming to a conclusion in a suspected case of hanging so as to avoid any erroneous opinion.

Key words: hanging, ligature material, ligature mark, classic signs, internal injuries, fractures

\section{INTRODUCTION}

Hanging, a form of ligature neck compression that involves suspension by the neck is a common method of suicide. ${ }^{1}$ The role of the forensic pathologist when body is found suspended is to give an opinion on the manner of death and to exclude or confirm other forms of neck compression prior to being hung. Correlation of the neck markings together with the internal findings are of extreme importance in arriving at a conclusion. It is easy to arrive at a conclusion when one finds the 'classical features' i.e. imprint/ patterned abrasion or parched appearance surrounding the neck with asphyxial features. $^{2}$ However all features are seldom present together. An autopsy of a hanged body will often reveal neck markings but the ligature may be absent. ${ }^{1}$ Findings resulting from application of pressure on the neck quite vary. ${ }^{2}$ Thus a Forensic pathologist is caught in a dilemma when there are atypical findings in addition to the typical ligature mark. A proper assessment of various post-mortem findings is therefore necessary to arrive at a conclusion.
The nature of the neck markings depends on the type of noose. ${ }^{1}$ According to existing literature, a noose made of soft material like a saree or a scarf is known to leave only a few marks or no mark at all leading to difficulties in interpretation. ${ }^{1} \mathrm{~A}$ rope or a cord noose will leave a deep furrow, often with accompanying abrasions. In the case of a typical suspension the mark will rise to an inverted "V" shape with a gap at the back. This is often used to distinguish a hanging from a ligature strangulation. However, in a hanging from a low suspension point, the marks on the neck tend to be horizontal rather than diagonal simulating ligature strangulation. ${ }^{3}$

The pattern of external and internal injuries and other postmortem findings resulting from neck compression permit a Forensic pathologist to resolve many unanswered questions. However, there are many exceptions to the rule with atypical findings. ${ }^{4}$ Thus, the experts in Forensic medicine must be aware of the exceptions in-order to arrive at balanced conclusions and scientifically based opinions.

In order to have an insight into the typical and atypical findings related to hanging we have conducted a retrospective descriptive study on deaths due to suicidal hanging reported to North Colombo Teaching Hospital, Ragama, Sri Lanka over a period of 3 years.

\section{OBJECTIVES}

The aim of the study was to analyze the findings of death investigation including autopsy in deaths due to hanging and to have an insight into the typical and atypical findings and the factors affecting them in order to appreciate the difficulties in interpretation. 


\section{METHODS}

A retrospective descriptive study was conducted on the post mortem records of the victims of hanging during 3 years from 2013 brought to Colombo North Teaching Hospital, Ragama of Sri Lanka. Autopsy reports, scene and postmortem photographs and other case materials such as copies of the police scene investigation findings were perused. The historical details, scene findings, findings of autopsy external and internal examinations, the results of the post-mortem investigations and the opinion and conclusions given were obtained according to a pro-forma designed to fulfil study objectives. All cases presented as suicidal hanging during the period were included. Bodies that were decomposed, suspicious of homicidal suspension and those with poor records were excluded from the study.

\section{ETHICAL CLEARANCE}

Since the study was performed based on documented findings of already performed autopsies, and no identifiable data was retrieved there was no necessity for ethical clearance. Permission to retrieve data was obtained from the medical officers who performed the autopsies and from the Director of the Colombo North Teaching Hospital, Ragama.

Data collected were entered in Microsoft excel worksheets and analysed using Statistical Package for Social Sciences (SPSS) for frequencies and comparisons. Graphs and tables are used as appropriate to present the data.

\section{RESULTS}

During the period of 3 years, there were 112 cases of suicidal hanging deaths. Of them, 97 (86.6\%) were males. Majority; 81 $(72.3 \%)$ was in the age group of $21-60$ years. (Table: 1 )
Table1: Age distribution of the study group

\begin{tabular}{|l|l|}
\hline Age group & Frequency \\
\hline$\leq 20$ yrs. & $9(8 \%)$ \\
\hline $21-40$ yrs. & $41(36.6 \% 0$ \\
\hline $41-60$ yrs. & $40(35.7 \%)$ \\
\hline$>60$ yrs. & $22(19.6 \%)$ \\
\hline Total & $112(100 \%)$ \\
\hline
\end{tabular}

Majority 78 (69.6\%) were found hanging in their own home followed by $32(28.6 \%)$ victims who were recovered from places that were known to the deceased. Only 2 $(1.8 \%)$ victims were found hanging at an unknown place.

There were $23(20.5 \%)$ of partial suspensions and $89(79.5 \%)$ complete suspensions. Problems or stress related to education were the reason for suicide in 44 (39\%) victims. 40 (35.7\%) had family disputes and $9(8 \%)$ committed suicide due to broken love affairs. There were $8(7.1 \%)$ who had multiple other reasons. Note of suicide was found in only $16(14.3 \%)$ cases.

Sixty one $(54.5 \%)$ had used a rope (coir $(25 \%)$ or a nylon $(29.5 \%)$ as ligature material. Twenty six (23.2\%) had used a soft fabric and 12 others had used various other materials including belts (10.7\%). Thirteen $(11.6 \%)$ were brought without a ligature.

Majority (102) were having only the imprint of ligature on the neck. While there were 6 having peri-ligature injuries in addition to the ligature mark. There were 4 $(3.6 \%)$ with no injuries to the neck. The pattern of the ligature mark was continuous in $92(82 \%)$. Twenty (20) out of 26 individuals who had used a soft fabric had a continuous ligature mark. The ligature mark was absent only in four of the victims and two of them were using a soft fabric. (Table: 2) 
Table 2: ligature material Vs pattern of ligature mark

\begin{tabular}{|l|l|l|l|l|}
\hline $\begin{array}{l}\text { Ligature Pattern of ligature } \\
\text { Material }\end{array}$ & $\begin{array}{l}\text { Intermittent } \\
\text { mattern }\end{array}$ & $\begin{array}{l}\text { Continuous } \\
\text { pattern }\end{array}$ & $\begin{array}{l}\text { No } \\
\text { ligature } \\
\text { mark }\end{array}$ & Total \\
\hline Soft fabric & 4 & 20 & 2 & 26 \\
\hline Coir rope & 4 & 24 & 0 & 28 \\
\hline Nylon rope & 4 & 28 & 1 & 33 \\
\hline Belt & 0 & 1 & 0 & 1 \\
\hline Other & 1 & 10 & 0 & 11 \\
\hline Not present & 3 & 9 & 1 & 13 \\
\hline Total & 16 & 92 & 4 & 112 \\
\hline
\end{tabular}

Ligature mark was rising to an inverted $\mathrm{V}$ in a majority $81(72.3 \%)$. However, there were 8 $(7.1 \%)$ with a horizontal ligature mark and $2(1.8 \%)$ with multiple marks. There were 17 $(15.2 \%)$ with variable pattern in their ligature mark while $4(3.6 \%)$ were having no ligature mark. The mark was placed high on the neck in 100 individuals. Eighty two (82) out of them were complete suspensions. Out of the 7 individuals with low ligature mark, 4 were partial suspensions. There was a significant difference between the two groups $(\mathrm{p}=0.018)$. (Table: 3$)$

Table3: degree of suspension Vs placement of the ligature mark

\begin{tabular}{|l|l|l|l|l|}
\hline $\begin{array}{l}\text { Degree Placement of } \\
\text { of hanging }\end{array}$ & $\begin{array}{l}\text { High on } \\
\text { the neck }\end{array}$ & $\begin{array}{l}\text { Lower on } \\
\text { the neck }\end{array}$ & $\begin{array}{l}\text { No ligature } \\
\text { mark }\end{array}$ & Total \\
\hline Partial & 18 & 4 & 1 & 23 \\
\hline Complete & 82 & 3 & 4 & 89 \\
\hline Total & 100 & 7 & 5 & 112 \\
\hline
\end{tabular}

The gap or the point of suspension was found at the back of the neck (center of occiput) in a $52(46 \%)$ while the mark was high on the neck in $51(98 \%)$ out of them. $29(85 \%)$ out of 34 individuals whose knot was found at the side had the ligature mark placed high on the neck. Out of the 7 low lying ligatures majority were having the point of suspension at the side of the neck. This was a statistically significant finding $(\mathrm{p}=0.018)$. (Table: 4)

Table 4: Placement of the ligature and placement of the point of suspension

\begin{tabular}{|l|l|l|l|l|l|}
\hline $\begin{array}{l}\text { Placement of } \\
\text { Placement } \\
\text { of gap }\end{array}$ & $\begin{array}{l}\text { High on } \\
\text { the neck }\end{array}$ & $\begin{array}{l}\text { Lower on } \\
\text { the neck }\end{array}$ & Other & $\begin{array}{l}\text { No ligature } \\
\text { mark }\end{array}$ & Total \\
\hline Back of the neck (center of occiput) & 51 & 1 & 0 & 0 & 52 \\
\hline Side behind the ear & 29 & 5 & 0 & 0 & 34 \\
\hline Front of the neck & 2 & 0 & 0 & 0 & 2 \\
\hline Other & 1 & 0 & 1 & 0 & 2 \\
\hline No gap & 17 & 1 & 0 & 0 & 18 \\
\hline No ligature mark & 0 & 0 & 0 & 4 & 4 \\
\hline Total & 100 & 7 & 1 & 4 & 112 \\
\hline
\end{tabular}


On the other hand, the degree of suspension did not show any significant association with the type of hanging; typical or atypical. $(\mathrm{p}=0.082)$ (Table: 5)

Table 5: Type of hanging Vs degree of suspension

\begin{tabular}{|c|c|c|c|}
\hline $\begin{array}{ll}\begin{array}{l}\text { Placement } \\
\text { of gap }\end{array} & \begin{array}{l}\text { Degree of } \\
\text { hanging }\end{array} \\
\end{array}$ & Partial & Complete & Total \\
\hline Typical hanging & 7 & 45 & 52 \\
\hline Atypical hanging & 16 & 44 & 60 \\
\hline Total & 23 & 89 & 112 \\
\hline
\end{tabular}

Classical signs were found in $41(36.6 \%)$ victims. Of them commonly observed classic sign was congestion $(29,25.9 \%)$ Twenty six out of 41 had petechial haemorrhages and 11 had oedema.

Presence of classic signs showed a statistically significant association to partial suspension $(\mathrm{P}<0.001))$. (Table: 6)

Table 6: Presence of classic signs Vs degree of suspension

\begin{tabular}{|l|l|l|l|}
\hline $\begin{array}{l}\text { Degree Classical } \\
\text { of hanging }\end{array}$ & Present & Absent & Total \\
\hline Partial & 17 & 6 & 23 \\
\hline Complete & 24 & 65 & 89 \\
\hline Total & 41 & 71 & 112 \\
\hline
\end{tabular}

Presence of classic signs did not show any significant association to the placement of the ligature mark. $(\mathrm{p}=0.6592)$ (Table: 7$)$

Table 7: Placement of ligature mark Vs classic signs

\begin{tabular}{|l|l|l|l|l|l|}
\hline $\begin{array}{l}\text { Classic } \\
\text { signs }\end{array}$ & $\begin{array}{l}\text { Placement of } \\
\text { ligature }\end{array}$ & $\begin{array}{l}\text { High on } \\
\text { the neck }\end{array}$ & $\begin{array}{l}\text { Lower on } \\
\text { the neck }\end{array}$ & $\begin{array}{l}\text { Other } \\
\text { ligature } \\
\text { mark }\end{array}$ & Total \\
\hline Present & 36 & 4 & 0 & 1 & 41 \\
\hline Absent & 64 & 3 & 1 & 3 & 71 \\
\hline Total & 100 & 7 & 1 & 4 & 112 \\
\hline
\end{tabular}

Internal injuries were observed in $38(33.9 \%)$ and it was found directly underlying the external injuries in36. Commonly observed internal injuries were fractures (33). Underlying contusions were found among 10 and 2 had haematomas. In a majority, the fractures were placed on the thyroid cartilage \& hyoid bone.

There is no significant association of the ligature material used with the presence or absence of internal injuries $(\mathrm{P}=0.351)$ (table: 8$)$. 
Table 8: Ligature material Vs internal injuries

\begin{tabular}{|c|c|c|c|}
\hline $\begin{array}{lr}\text { Ligature } & \begin{array}{r}\text { Internal } \\
\text { injury } \\
\text { Material }\end{array}\end{array}$ & Present & Absent & Total \\
\hline Soft fabric & 10 & 16 & 26 \\
\hline Coir rope & 12 & 16 & 28 \\
\hline Nylon rope & 7 & 26 & 33 \\
\hline Belt & 0 & 1 & 1 \\
\hline Other & 5 & 6 & 11 \\
\hline Not present & 4 & 9 & 13 \\
\hline Total & 38 & 74 & 112 \\
\hline
\end{tabular}

$70 \%$ of the victims of complete suspension and $52 \%$ of the individuals with partial suspension had no internal injuries. Further, there is no significant difference between the two groups; partial and complete suspension concerning presence of internal injuries. $(p=0.11)$ (Table: 9$)$

Table 9: Partial or complete Vs internal injuries

\begin{tabular}{|l|l|l|l|}
\hline $\begin{array}{c}\text { Internal } \\
\text { of hegree } \\
\text { injury }\end{array}$ & Present & Absent & Total \\
\hline Partial & $11(48 \%)$ & $12(52 \%)$ & 23 \\
\hline Complete & $27(30 \%)$ & $62(70 \%)$ & 89 \\
\hline Total & 38 & 74 & 112 \\
\hline
\end{tabular}

\section{DISCUSSION}

In addition to the typical autopsy findings described, various atypical findings associated with death due to hanging are reported. The appearance of ligature mark and other findings at the autopsy depend on many factors.

This study revealed that the majority of the deaths due to hanging were of males who were young to middle aged. This is very well described in other studies as well. ${ }^{5}$ Majority $(70 \%)$ were found hanging inside their home. This is reported in many other studies as well..$^{6,7,8}$ Easy accessibility and the secluded environment may be the underlying reason for this finding. In a study on survivors of near fatal suicide attempts, it was found that the victims had
Considered hanging as an easy and straightforward method both in terms of access to materials and ease of implementation. ${ }^{9}$ This was further confirmed in our study as well.

In this study the majority (80\%) were complete suspensions. Findings were similar to this in many studies conducted in India ${ }^{8,10,11,12}$ though there were few studies in which they have found partial suspension as a common presentation. ${ }^{13}$

Issues related to education was the underlying reason for suicide among majority (39\%) followed by family disputes. Risk factors for suicide vary according to country, culture, religion, gender, age, and social values. ${ }^{14}$ There is an increasing concern regarding study 
pressure and its relationships with mental health problems. It is known that academic stress is associated with depression among adolescents. $^{15}$ The findings highlight the importance of targeting preventive strategies on the victims of highly competitive academic environment in this country. In a study done among the lower socioeconomic rural population depressive disorders, other psychiatric disorders and family matters were identified as the major risk factors for suicide. ${ }^{16}$

Finding a note of suicide is a strong corroborative evidence in concluding the manner of death. However, a note of suicide was found only in $16(14.3 \%)$ cases. In a study done in Japan, the mean incidence of finding a note of suicide was 30.1\%. ${ }^{17}$ There may be cultural, ethnic, and racial variations associated with this behavior.

$55 \%$ of the victims had used coir or a nylon rope as the ligature material followed by a soft fabric in $23 \%$. This can be explained from easy availability and accessibility of nylon or coir ropes used for domestic work in Sri Lanka. Vipul, NamdeoraoAmbade et al found $62 \%$ of the victims were using a nylon rope as a ligature material in their study on ligature material used in hanging deaths. ${ }^{8}$ Further, many other studies from Asia reports rope as the commonest ligature material ${ }^{18}$. There are other studies reporting soft fabric as the commonest ligature material which again can be considered as a cultural variation. ${ }^{19}$

A ligature mark was observed in $96 \%$. There were associated peri-ligature injuries in $5.4 \%$ individuals. Mohammed Musaib M. Shaikh found peri-ligature injuries in the form of abrasion bruise and rope burns in $16.28 \%$ cases of hanging. ${ }^{20}$ Nail marks over the neck are usually suggestive of manual strangulation and may mislead the forensic pathologist in drawing conclusions. However, they are also known to be caused as self-inflicted by the victim while trying to remove him/herself from the strangling grip of hanging at the last moment. ${ }^{21}$

The pattern of the ligature mark was continuous in $82 \%$ out of them. Even in individuals who had used a soft fabric majority had a continuous ligature mark. The ligature mark was absent only in 4 of the victims and 2 of them were using a soft fabric. Studies on the pattern of ligature mark being compared with the ligature material are scarce. ${ }^{19,22,23}$ Our study revealed that there is no significant correlation of the pattern of the ligature mark to the ligature material.

The ligature mark was found high on the neck in 100 individuals and was rising to an inverted " $v$ " shape in $72 \%$. Association of complete suspension with a high ligature mark was observed in our study with a statistical significance. It is reported in other studies as well where partial suspension is found commonly associated with low ligature mark. ${ }^{24}$ The high and rising / oblique ligature mark is described as a differentiating factor of hanging and ligature strangulation and it has been repeatedly shown in many studies. ${ }^{20}$

The mark was rising towards the point of suspension or the knot was found at the back of the neck (typical hanging) in $46 \%$ followed by behind the ear in $30 \%$. Thus the majority belonged in the group of atypical hanging where the knot is not at the back of the neck. This is commonly described in many other studies. ${ }^{2,25}$ There was a significant association of the placement of the point of suspension whether back or front or side with the placement of ligature mark on the neck where high ligature was found to show an association with point of suspension at the back while low lying ligature was having an association with point of suspension at the side. However, there was no significant association of the degree of suspension with the placement of the knot. Many studies 
have reported majority adopting complete and atypical hanging. ${ }^{26}$

Majority of the victims were not having classic signs (63\%). Commonly observed "classic sign" was congestion followed by petechial haemorrhages. Classic signs were absent in majority of complete suspensions while they were commonly observed in partial suspensions with a statistically significant association $(\mathrm{p}<0.001)$. Classic signs are a result of purely mechanical vascular phenomena or obstructed venous return in the presence of continued arterial input. As pressure builds in venules and capillaries, particularly those with little surrounding connective tissue support, such as the conjunctivae and eyelids, vascular rupture produces petechiae. ${ }^{27}$ Since partial suspension is adequate to obstruct the veins while arterial supply is continuing theoretically, classic signs are more commonly observed in partial suspensions though only few scientific studies are available to support this finding. ${ }^{28}$ Our study further confirmed the theory and revealed a significant difference in presence of classic signs in partial suspensions compared to the complete suspension. On the other hand, high or low placement of ligature mark did not show any significant association to the presence of classic signs.

Internal injuries were absent in a majority. When present, they were found directly underlying the ligature mark in a majority. The commonest nature of the internal injury was fractures and they involved the thyroid cartilage or hyoid bone.
This contrast with other studies where internal injuries were commonly observed and the nature was soft tissue contusions. ${ }^{29}$ Since the study was done retrospectively, possible handling artifacts at evisceration and proper documentation and discrimination cannot be assured. This suggested the need for a prospective study. There is no significant statistical association of presence or absence of internal injuries with the type of suspension; partial and complete or the ligature material used. This has been described in other studies as well. ${ }^{30}$

\section{CONCLUSION}

Correct interpretation of autopsy findings in a case of hanging is of extreme importance in making a confirmatory diagnosis of death owing to hanging. Our study revealed that the findings vary and could be found in many combinations, sometimes with exceptions to the generally accepted. Awareness of these combinations and the exceptions are of crucial importance in coming to a conclusion in a suspected case of hanging so as to avoid any erroneous opinion. Findings in our study confirmed the existing literature in many occasions but contrasted in some especially with regards to type of internal injury. This was identified as a limitation in a retrospective study where there is a possibility of handling artifacts. 


\section{REFERENCES}

1. Sharma B. R., Harish D, Pal Singh V, Singh P. Ligature mark on neck: how informative?. JIAFM, 2005 : 27 (1).10-15.

2. Meera, M. Singh B K. Pattern of Neck Findings in Suicidal Hanging. A Study in Manipur. J Indian Acad Forensic Med. Oct 2011, Vol. 33, No. 4. 352 - 354.

3. Rao D. An autopsy study of death due to Suicidal Hanging - 264 cases, Egypt J Forensic Sci (2015), http://dx.doi.org/ 10.1016/j.ejfs.2015.01.004.

4. Cooke, C.T., Cadden, G.A., \& Hilton, J.M. Unusual Hanging Deaths. Am J Forensic Med Pathol: Dec 1988. Volume 9. Issue 4 pp: 277-365.

5. Chandegara P, Patel J, Zanzrukiya K, Patel U, Parkhe S, Gajera C, et al. Sociodemographic profile of hanging cases at New Civil Hospital, Surat.Int J Med Sci Public Health. 2014; 3(12): 1474-1477.doi: 10.5455/ijmsph.2014.130920141.

6. Vijayakumari N. Suicidal hanging: a prospective study. J Indian Acad Forensic Med, 33 (4) (2011), pp. 355-357.

7. Ahmad M, Hossain M. Z. Hanging as a method of suicide: Retrospective analysis of postmortem cases. J AFMC, Bangladesh, 6 (2) (2010), pp. 37-3.

8. Ambade $\mathrm{V} \mathrm{N}$, Tumram N, Meshram S, Borkar J. Ligature material in hanging deaths: The neglected area in forensic examination. Egypt J Forensic Sci. Volume 5, Issue 3, Sep 2015, Pages 109-11.

9. Biddle L, Donovan J, Owen-Smith A, Potokar J, Longson D, Hawton K, et al. Factors influencing the decision to use hanging as a method of suicide: qualitative study. Br J Psychiatry. Sep 2010, 197 (4) 320-325;

DOI: 10.1192/bjp.bp.109.076349.
10. Sharma BR, Harish D, Sharma A, Sharma $\mathrm{S}$, Singh H. Injuries to neck structures in deaths due to constriction of neck, with a special reference to hanging. J Forensic Legal Med 2008 Jul;15(5): 298-305.

11. Saisudheer T, Nagaraja TV. A study of ligature mark in cases of hanging deaths. Int J Pharm Biomed Sci 2012;3(3):80-4.

12. Rao D. An autopsy study of death due to Suicidal Hanging - 264 cases. Egypt J Forensic Sci. 6; (3): Sep 2016, Pp 248-254 http://dx.doi.org/10.1016/j.ejfs.2015.01.00 4.

13. Dean DE, Kohler LJ, Sterbenz GC, Gillespie PJ, Gonzaga NS, Bauer LJ, et al. Observed characteristics of suicidal hangings: an11-year retrospective review. J Forensic Sci 2012 Sep;57(5):1226-30.

14. Wasnik RN. A two year study of suicidal deaths in Nagpur, central India. Indian J Forensic Med Toxicol. 2012;6:85-8.

15. P J Ayanthi, M T HirunavukarasuAnd, RajamanickamRajkumar Academic Stress and Depression among Adolescents: A Cross-sectional Study. Indian Pediatrics. Volume 52 Mar 15, 2015; 217-219.

16. Kosaraju SKM, Vadlamani LN, Mohammed Bashir MS, Kalasapati LK, Rao GLVC, Rao GP. Risk Factors for Suicidal Attempts Among Lower Socioeconomic Rural Population of Telangana Region. Indian J Psychol Med. 2015;37(1):30-35. doi:10.4103/02537176.150813 .

17. Shioiri T, Nishimura A, Akazawa K, Abe $\mathrm{R}$, Nushida $\mathrm{H}$, Ueno $\mathrm{Y}$, et al. Incidence of note-leaving remains constant despite increasing suicide rates. Psychiatry and Clinical Neurosciences (2005); 59, 226228.

18. Pradhan A, Mandal BK, Tripathi CB. Hanging: nature of ligature material applied and type of hanging according to point of suspension. Nepal Med Coll J. 2012 Jun;14(2):103-6. 
19. Momin S G., Mangal H M, Kyada H C., Vijapura M.T., Bhuva S.D.. Pattern of Ligature Mark in Cases of Compressed Neck in Rajkot Region: A Prospective Study. J Indian Acad Forensic Med. JanMar 2012; 34 ( 1):40-43.

20. Shaikh M M M, Chotaliya H. J., Modi A.D., Parmar A. P., Kalele S. D.. A Study of Gross Postmortem Findings in Cases of Hanging and Ligature Strangulation. J Indian Acad Forensic Med. Jan-Mar 2013;35(1): 63-65.

21. Mohanty MK, Rastogi P, Kumar GP, Kumar V, Manipady. Periligature injuries in hanging. SJ Clin Forensic Med. 2003 Dec;10(4):255-8.

22. Arif M. Ligature mark on the neck; How elucidative? Professional Med J 2015;22(6):798-803.

23. Bhausaheb NA, Baburao CS, Banerjee KK, Kohli A. Pattern of external and internal findings in deaths owing to hanging - a study in Northeast Delhi. Int J Med Sci Public Health 2015;4:1536-1539.

24. Jayaprakash S, Sreekumari K. Pattern of injuries to neck structures in hanging-an autopsy study. Am J Forensic Med Pathol. 2012 Dec;33(4):395-9.

DOI: 10.1097/PAF.0b013e3182662761.
25. Talukder MA, Mansur MA, Kadir MM. Incidence of typical and atypical hanging among 66 hanging cases. Mymensingh Med J. 2008 Jul;17(2):149-51.

26. Samanta A K, Nayak S R. Newer Trends in Hanging Death. J Indian Acad Forensic Med. Jan March 2012; 34 (1): 37-39.

27. Ely SF, Hirsch CS. Asphyxial deaths and petechiae: a review. J Forensic Sci 2000;45(6):1274-1277.

28. Clément R, Guay JP, Redpath M, Sauvageau A. Petechiae in hanging: a retrospective study of contributing variables. Am J Forensic Med Pathol. 2011 Dec;32(4):378-82.

DOI: 10.1097/PAF.0b013e3181db7ecf.

29. Vinita VE, Paul PM, Janani, Kumar PS. Pattern of neck tissue injuries in hanging -a prospective study. J Punjab Acad Forensic Med Toxicol 2014;14(2). 1-1-104.

30. Worawat A, Wongchanapai W, Thamtakerngkit S. Factors affecting neck injuries in hanging deaths. J Forensic Phys Assoc. 2008;2:23-32. 